Abstracta Iranica Iranica

Revue bibliographique pour le domaine irano-aryen

Volume 37-38-39 | 2018

Comptes rendus des publications de 2014-2016

\title{
Janet Afary, John R. Perry (eds. \& transl.). Ali Akbar Dehkhoda Charand-o Parand: Revolutionary Satire from Iran, 1907-1909
}

\section{Laetitia Nanquette}

\section{(2) OpenEdition \\ Journals}

Electronic version

URL: http://journals.openedition.org/abstractairanica/51396

DOI: 10.4000/abstractairanica.51396

ISBN: 1961-960X

ISSN: 1961-960X

Publisher:

CNRS (UMR 7528 Mondes iraniens et indiens), Éditions de l'IFRI

\section{Electronic reference}

Laetitia Nanquette, « Janet Afary, John R. Perry (eds. \& transl.). Ali Akbar Dehkhoda Charand-o Parand:

Revolutionary Satire from Iran, 1907-1909 », Abstracta Iranica [Online], Volume 37-38-39 | 2018,

document 7, Online since 30 December 2018, connection on 10 December 2020. URL : http://

journals.openedition.org/abstractairanica/51396; DOI : https://doi.org/10.4000/abstractairanica. 51396

This text was automatically generated on 10 December 2020 .

Tous droits réservés 


\title{
Janet Afary, John R. Perry (eds. \& transl.). Ali Akbar Dehkhoda Charand- o Parand: Revolutionary Satire from Iran, 1907-1909
}

\author{
Laetitia Nanquette
}

\section{REFERENCES}

Janet Afary, John R. Perry (eds. \& transl.). Ali Akbar Dehkhoda Charand-o Parand: Revolutionary Satire from Iran, 1907-1909. 2016, Yale University Press

1 This book is the first translation into English of Charand-o Parand (Stuff and Nonsense) by Ali Akbar Dehkhoda, prominent writer and scholar of the Constitutional revolution. This work was first published as columns in the newspaper Sur-e Esrafil. Dehkhoda criticised the religious and political establishment of the time, as well as the colonial powers, through satirical pieces. His columns were widely circulated.

2 The translation by Janet Afary and John R. Perry is fluid and manages to give vivacity to Dehkhoda's language, which uses lots of proverbs and expressions and aims to be close to the language of the people. The book contains useful notes to explain the allusions to historical events and characters. A welcome introduction presents the background of the writer, the text and the Constitutional revolution. This is an essential reading for scholars working on constitutionalism in Iran, on journalism in Iran and on modern Persian prose. 


\section{AUTHORS}

\section{LAETITIA NANQUETTE}

University of New South Wales, Sydney 